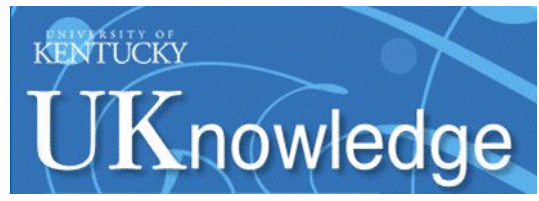

University of Kentucky UKnowledge

$12-2008$

\title{
Aluminum Bioavailability from Tea Infusion
}

Robert A. Yokel

University of Kentucky, ryokel@email.uky.edu

Rebecca L. Florence

University of Kentucky, rlstep2@uky.edu

Right click to open a feedback form in a new tab to let us know how this document benefits you. Follow this and additional works at: https://uknowledge.uky.edu/ps_facpub

Part of the Pharmacy and Pharmaceutical Sciences Commons 


\section{Aluminum Bioavailability from Tea Infusion}

Digital Object Identifier (DOI)

http://dx.doi.org/10.1016/j.fct.2008.09.041

Notes/Citation Information

Published in Food and Chemical Toxicology, v. 46, no. 12, p. 3659-3663.

(c) 2008 Elsevier Ltd. All rights reserved.

This manuscript version is made available under the CC-BY-NC-ND 4.0 license

http://creativecommons.org/licenses/by-nc-nd/4.0/ 
(C) 2008 Elsevier Ltd. All rights reserved.

This manuscript version is made available under the CC-BY-NC-ND 4.0 license http://creativecommons.org/licenses/by -nc-nd $/ 4.0 /$ 
Food Chem Toxicol. 2008 December ; 46(12): 3659-3663. doi:10.1016/j.fct.2008.09.041.

\title{
Aluminum bioavailability from tea infusion
}

\author{
Robert A. Yokel ${ }^{a, b}$ and Rebecca L. Florence ${ }^{a}$ \\ aDepartment of Pharmaceutical Sciences, College of Pharmacy, University of Kentucky Academic Medical \\ Center, 725 Rose Street, Lexington, KY 40536-0082, USA \\ bGraduate Center for Toxicology, University of Kentucky Academic Medical Center, Lexington, KY \\ 40536-0305, USA
}

\begin{abstract}
The objective was to estimate oral Al bioavailability from tea infusion in the rat, using the tracer ${ }^{26} \mathrm{Al} .{ }^{26} \mathrm{Al}$ citrate was injected into tea leaves. An infusion was prepared from the dried leaves and given intra-gastrically to rats which received concurrent intravenous ${ }^{27} \mathrm{Al}$ infusion. Oral $\mathrm{Al}$ bioavailability $(\mathrm{F})$ was calculated from the area under the ${ }^{26} \mathrm{Al}$, compared to ${ }^{27} \mathrm{Al}$, serum concentration $\times$ time curves. Bioavailability from tea averaged $0.37 \%$; not significantly different from water $(\mathrm{F}=0.3 \%)$, or basic sodium aluminum phosphate (SALP) in cheese $(\mathrm{F}=0.1$ to $0.3 \%)$, but greater than acidic SALP in a biscuit $(\mathrm{F}=0.1 \%)$. Time to maximum serum ${ }^{26} \mathrm{Al}$ concentration was $1.25,1.5,8$ and $4.8 \mathrm{~h}$, respectively. These results of oral Al bioavailability $\times$ daily consumption by the human suggest tea can provide a significant amount of the $\mathrm{Al}$ that reaches systemic circulation. This can allow distribution to its target organs of toxicity, the central nervous, skeletal and hematopoietic systems. Further testing of the hypothesis that Al contributes to Alzheimer's disease may be more warranted with studies focusing on total average daily food intake, including tea and other foods containing appreciable $\mathrm{Al}$, than drinking water.
\end{abstract}

\section{Keywords}

Accelerator mass spectrometry; Aluminum; Atomic absorption spectrometry; Oral bioavailability; Rat; Tea beverage

\section{Introduction}

Aluminum ( $\mathrm{Al}$ ) can produce toxicity to the central nervous, skeletal and hematopoietic systems. It can produce an encephalopathy in renal-impaired humans (dialysis encephalopathy), cognitive deficits in young children, a low-turnover bone disease, and a microcytic hypochromic anemia. It has been controversially implicated as an environmental factor that may contribute to some neurodegenerative diseases, including Alzheimer's disease (AD) (Krewski et al., 2007; Sjögren et al., 2007). The primary dietary source of Al in the U.S. for the typical human is foods and beverages, including tea. Average daily $\mathrm{Al}$ intake is typically

Corresponding author: Robert A. Yokel, Ph.D., 511C Pharmacy Building, 725 Rose Street, University of Kentucky Academic Medical Center, Lexington, KY 40536-0082, phone: 859-257-4855, fax: 859-323-6886, e-mail: ryokel@email.uky.edu.

Publisher's Disclaimer: This is a PDF file of an unedited manuscript that has been accepted for publication. As a service to our customers we are providing this early version of the manuscript. The manuscript will undergo copyediting, typesetting, and review of the resulting proof before it is published in its final citable form. Please note that during the production process errors may be discovered which could affect the content, and all legal disclaimers that apply to the journal pertain.

Financial disclosure

The authors report no conflicts of interest for this work. 
5 to $10 \mathrm{mg}$ (Pennington and Schoen, 1995). Drinking water provides $\sim 0.1 \mathrm{mg}$ of $\mathrm{Al}(\sim 1.5 \%$ of total daily dietary $\mathrm{Al}$ intake) whereas in countries where $\mathrm{Al}$ from other sources is relatively small and tea consumption relatively large, as in the UK, tea may contribute up to $50 \%$ of total daily Al intake (UKMAFF, 1993). In a defined diet study conducted in Australia to estimate oral $\mathrm{Al}$ absorption, instant tea provided $1.8 \mathrm{mg} \mathrm{Al} / 1,>50 \%$ of the $3.2 \mathrm{mg} \mathrm{Al}$ consumed daily (Stauber et al., 1999). Tea infusions typically contain 2 to $4 \mathrm{mg} \mathrm{Al} / \mathrm{l}$ (Sepe et al., 2001; Flaten, 2002). Herbal tea infusions contain less $\mathrm{Al}$ (Hayacibara et al., 2004). Antiperspirants, vaccines, allergy desensitization injections and Al-based oral anti-acids can contribute significant amounts to total human Al exposure in some people (Yokel and McNamara, 2001; Yokel, 2004; Krewski et al., 2007).

Oral bioavailability (fractional absorption) is the amount absorbed compared to the amount administered. Oral Al bioavailability has been estimated in a number of studies, reviewed by Yokel and McNamara (2001) with more recent studies reported by Steinhausen et al. (2004) and Zhou et al. (2008). Because it was suggested that Al bioavailability from water is greater than from food (Martyn et al., 1989), the primary interest has been to model drinking water Al consumption. The greater bioavailability was attributed to organic ligands in food, such as phytates and polyphenols, that were suggested to complex $\mathrm{Al}$ and inhibit its oral absorption (Reto et al., 2007). Determination of oral Al bioavailability from food is complicated by the many different types of available foods, and their different methods of preparation, including ingredients. Organic ligands bind > 90\% of Al in tea (Gardner and Gunn, 1995). Their identity has not been determined, although polyphenolic and oxalate complexes have been suggested (Flaten, 2002).

Oral aluminum bioavailability has been estimated using several methods. These were reviewed and critiqued by Yokel and McNamara (Yokel and McNamara, 2001). The standard method to determine oral bioavailability is the comparison of areas under the plasma/serum concentration-time curve after po and iv administration in the same subjects (Rowland and Tozer, 1995; Bauer, 2006). The po and iv doses can be administered concurrently when the test substance is given as two analytically distinguishable, but biologically indifferent, chemical species. In this study, the use of ${ }^{26} \mathrm{Al}$, which is not present in the environment or in normal biological organisms, was incorporated as a tracer in the oral dose (tea infusion). The use of ${ }^{26} \mathrm{Al}$ to study $\mathrm{Al}$ toxicokinetics was reviewed (Flarend and Elmore, 1998). ${ }^{26} \mathrm{Al}$ was analyzed by accelerator mass spectrometry (AMS), which measures the ${ }^{26} \mathrm{Al} /{ }^{27} \mathrm{Al}$ ratio with a detection limit of $\sim 1,000,000{ }^{26} \mathrm{Al}$ atoms. The use of ${ }^{26} \mathrm{Al}$ enables the conduct of physiologically-relevant pharmacokinetic studies of $\mathrm{Al} .{ }^{27} \mathrm{Al}$ was concurrently administered as the iv dose. Electrothermal atomic absorption spectrometry was utilized to quantify total $\mathrm{Al}$, essentially the ${ }^{27} \mathrm{Al}$ from its iv administration because the concentration of ${ }^{27} \mathrm{Al}$ was orders of magnitude greater than ${ }^{26} \mathrm{Al}$. This method was used to address the objective of the present study; to estimate oral Al bioavailability from tea infusion in the rat.

\section{Methods}

\section{Materials}

${ }^{26} \mathrm{Al}$ was provided by the Purdue Rare Isotope Measurement Laboratory (PRIME Lab). It was supplied as $16.5 \mathrm{nCi}(865 \mathrm{ng}){ }^{26} \mathrm{Al} / \mathrm{ml}$ and with a $34: 1{ }^{27} \mathrm{Al}:{ }^{26} \mathrm{Al}$ ratio $(30.3 \mu \mathrm{g}$ total $\mathrm{Al} / \mathrm{ml})$ in $0.01 \mathrm{~N} \mathrm{HCl}$.

Hydroponic studies were conducted in collaboration with Dr. Jack Buxton, Department of Horticulture, University of Kentucky, to incorporate $\mathrm{Al}$ into the spinach plant in the same chemical species as it is present in situ. We were not able to produce sufficient Al loading for an oral bioavailability study. It was concluded that this approach would not be practical for the tea plant (Camellia sinensis). Therefore, $\mathrm{Al}$ was injected into the central vein at the base of the 
tea leaf. Al was injected as the citrate because Al taken up from the soil was shown to be associated with charged organic compounds present in symplasm, predominantly citrate (Kochian and Jones, 1997) and Al citrate added to nutrient solution was transported from plant roots to the upper part of plants unchanged (Polak et al., 2001). In preliminary studies using ${ }^{27} \mathrm{Al}$, we found $85 \%$ of the $\mathrm{Al}$ infused into the base of the tea leaf to be taken up from the central vein into the leaf. When powdered leaf was placed in boiling water, $77 \%$ of the Al was recovered in the infusate.

To prepare a tea infusion containing ${ }^{26} \mathrm{Al}, 3 \mathrm{ml}$ of ${ }^{26} \mathrm{Al}$ solution, containing $50 \mathrm{nCi}(2620$ ng) ${ }^{26} \mathrm{Al}$, and $90,000 \mathrm{ng}{ }^{27} \mathrm{Al}$, were dried to a powder to which was added $96.9 \mu 11 \mathrm{M} \mathrm{Al}$ and $300 \mu \mathrm{l} 1 \mathrm{M}$ citrate and $\mathrm{pH}$ adjusted to 3.11 to optimize Al citrate formation. Speciation calculations suggested $>99 \%$ of the $\mathrm{Al}$ would be associated with citrate; $45 \%$ as $\mathrm{Al}$ (citrate $)_{2}, 30 \%$ as $\mathrm{Al}_{3}\left(\mathrm{H}_{-1} \text { citrate }\right)_{3}(\mathrm{OH}), 14 \%$ as $\mathrm{Al}_{2}\left(\mathrm{H}_{-1} \text { citrate }\right)_{2}, 9 \%$ as $\mathrm{Al}$ (citrate), $<0.002 \%$ as free $\mathrm{Al}$ and the remainder other $\mathrm{Al}$ citrate species (personal communication from Dr. Wesley Harris, University of Missouri-St. Louis). One hundred $\mu \mathrm{l}$ was infused over $10 \mathrm{~h}$ into the base of each of four tea leaves. Total Al in the $100 \mu \mathrm{l}$ was $0.65 \mathrm{mg}$, delivering the same amount of $\mathrm{Al}$ as is inherently in tea leaves $(0.5$ to $1 \mathrm{mg} / \mathrm{gm})$. The central vein of each leaf was dissected out and the remainder dried overnight at $70{ }^{\circ} \mathrm{C}$. The leaves (totaling $1.1 \mathrm{~g}$ dry weight) were ground to a powder in a coffee grinder and transferred into an emptied commercial tea bag. To maximize Al extraction the bag was placed in $20 \mathrm{ml}$ of boiling MilliQ water in a $50 \mathrm{ml}$ plastic tube, gently agitated and allowed to steep for 30 minutes. The fluid was squeezed from the bag into the infusate, which was refrigerated. Fine particles were allowed to settle and the supernatant removed and divided into $1 \mathrm{ml}$ aliquots that were frozen until the day of dosing to rats. A similar tea infusate was prepared without ${ }^{26} \mathrm{Al}$ by similarly infusing tea leaves with non- ${ }^{26} \mathrm{Al}$ containing $\mathrm{Al}$ citrate and preparation of an infusion by steeping $500 \mathrm{mg}$ of tea in 10 $\mathrm{ml}$ water. It was administered to a sentinel rat to document sample contamination.

The ${ }^{26} \mathrm{Al}$ concentration in the tea infusion was determined. Five samples of the tea infusion dosing material (mean \pm S.D., $20.9 \pm 3.4 \mathrm{mg}$ ) were diluted 4 times, each a 10-fold dilution, serially, with MilliQ water. One ml was transferred to a porcelain crucible to which $4 \mathrm{mg} \mathrm{Al}$ (Aldrich ICP/DCP standard) was added. The samples were dried over night then slowly heated to $1000{ }^{\circ} \mathrm{C}$ in a muffle furnace to convert the $\mathrm{Al}$ to $\mathrm{Al}$ oxide, which was analyzed by accelerator mass spectrometry. The tea infusion was found to contain $1.36 \mathrm{nCi}(71.3 \mathrm{ng}){ }^{26} \mathrm{Al} / \mathrm{ml}$.

\section{Animals}

The subjects were 9 male Fisher 344 rats, weighing $312 \pm 5 \mathrm{~g}$ (mean \pm SD). They were housed in the University of Kentucky Division of Laboratory Animal Resources facility at 30-70\% humidity and $65-75^{\circ} \mathrm{F}$. Animal work was approved by the University of Kentucky Institutional Animal Care and Use Committee. The research was conducted in accordance with the Guiding Principles in the Use of Animals in Toxicology. Eight of the nine rats were given an intragastric administration of tea infusion containing ${ }^{26} \mathrm{Al}$. One sentinal rat was given an intragastric administration of tea infusion not containing ${ }^{26} \mathrm{Al}$, to document sample contamination.

\section{Experimental procedures}

The rats were acclimated to a $10 \%$ protein diet designed to minimize food retention in the stomach (Harlan Teklad 95215). It contained $10 \pm 0 \mathrm{mg} \mathrm{Al} / \mathrm{kg}$ (triplicate analysis). They had free food access from 08:00 to 18:00 h daily for $\geq 5$ days prior to the determination of oral $\mathrm{Al}$ bioavailability. This diet was shown to result in the absence of food in the stomach $14 \mathrm{~h}$ after its withdrawal when fecal recycling (coprophagia) was prevented by a fecal collection cup, as described by Yokel et al. (2001). Deionized drinking water was freely available throughout the study except for the period from $14 \mathrm{~h}$ before to $4 \mathrm{~h}$ after oral dosing. It contained $5 \mu \mathrm{g} \mathrm{Al} /$ 1 . 
The rats were implanted with two femoral venous cannulae 1 day prior to intra-gastric administration of oral tea infusion. This enabled iv administration of ${ }^{27} \mathrm{Al}$ through one cannula and blood withdrawal from another, to avoid contamination of withdrawn blood by the administered Al.

The rats were randomly assigned to be given $1 \mathrm{ml}$ of tea infusion containing ${ }^{26} \mathrm{Al}(\mathrm{n}=8)$, in the absence of food in the stomach, or similarly dosed with tea infusion containing no ${ }^{26} \mathrm{Al}$ (n $=1$ ). Quantification of tea infusion delivery was determined by weighing the solution in a microtube. It was delivered intra-gastrically to the rat via gavage needle. Oral bioavailability calculations were based on the weight of administered tea infusion.

Oral Al bioavailability was determined in the un-anesthetized rat. Based on the results of a pilot study, the rats were iv infused at $100 \mu \mathrm{g} \mathrm{Al} / \mathrm{kg} / \mathrm{h}$ to produce an estimated $500 \mu \mathrm{g} \mathrm{Al} / \mathrm{l}$ in blood plasma for the ${ }^{27} \mathrm{Al}$ dose, as described by Yokel et al. (2001). In this study $\mathrm{AlK}\left(\mathrm{SO}_{4}\right)_{2}$ was continuously infused from $14 \mathrm{~h}$ prior to $60 \mathrm{~h}$ after oral dosing. Blood was withdrawn immediately before and 1, 2, 4, 8, 24, 36, 48 and $60 \mathrm{~h}$ after oral dosing. These sample times were based on two similar studies in which rats were given oral Al solution. In the initial study blood samples were obtained to $120 \mathrm{~h}$ after administration of ${ }^{26} \mathrm{Al}$ in water. However, the ${ }^{26} \mathrm{Al}$ in only two samples beyond $24 \mathrm{~h}$ met the criteria to be reliably above pre-treatment serum values. Therefore, the results were essentially based on samples up to $24 \mathrm{~h}$, as described by Yokel et al. (2001). In the second study in which ${ }^{26} \mathrm{Al}$ was given in water in the presence of various ligands, blood samples were obtained to $24 \mathrm{~h}$ (Zhou et al., 2008). The sampling times of the present study included 36,48 and $60 \mathrm{~h}$, to enable comparison to two other similarlyconducted studies in which ${ }^{26} \mathrm{Al}$ was incorporated into foods, and to assure sufficient time for total $\mathrm{Al}$ absorption (Yokel and Florence, 2006; Yokel et al., 2008). The blood withdrawn (0.3 $\mathrm{ml}$ for the 0 to $4 \mathrm{~h}$ samples, $0.5 \mathrm{ml}$ for the $8 \mathrm{~h}$ sample, $2.1 \mathrm{ml}$ at $24 \mathrm{~h}, 3.1 \mathrm{ml}$ at $36 \mathrm{~h}$, and 4.1 $\mathrm{ml}$ at $48 \mathrm{~h}$ ), was replaced by an equal volume of injected saline. Additionally, the rats had free access to water and food (Harlan Teklad 95215 diet) beginning $4 \mathrm{~h}$ after dosing. The $60 \mathrm{~h}$ blood sample was obtained by anesthetizing the rat and exsanguination from a femoral cannula and then the heart. Serum was obtained for ${ }^{26} \mathrm{Al}$ and ${ }^{27} \mathrm{Al}$ analysis. Blood urea nitrogen (BUN) and serum creatinine were determined in the $60 \mathrm{~h}$ sample.

\section{Preparation and analysis of total Al by electrothermal atomic absorption spectrometry}

The procedures were as recently described by Yokel and Florence (2006).

\section{Preparation and analysis of ${ }^{26} \mathrm{Al}$ by accelerator mass spectrometry}

The procedures were as described by Yokel et al. (2001).

\section{Data analysis}

A criterion for acceptance of post-treatment serum ${ }^{26} \mathrm{Al}$ concentrations considered to be reliably above pre-treatment serum values was established as $>2$ SD above the mean pretreatment serum ${ }^{26} \mathrm{Al}$ concentration. This criterion was 2 pg ${ }^{26} \mathrm{Al} / \mathrm{l}$. Values below this criterion are not presented graphically and were not used in the data analysis. This criterion was met by all of the samples obtained in the ${ }^{26} \mathrm{Al}$-dosed rats except one value at $60 \mathrm{~h}$. The results were analyzed using the pharmacokinetic-pharmacodynamic modeling and analysis program WinNonLin, using non-compartmental analysis (Pharsight, 2008). Each rat's pre-treatment serum ${ }^{26} \mathrm{Al}$ concentration was subtracted from its post-treatment values. Oral ${ }^{26} \mathrm{Al}$ bioavailability (F) was calculated as follows and expressed as a percent:

$$
\mathrm{F}=\frac{\text { The sum of the trapezoidal areas for }{ }^{26} \mathrm{Al}}{\text { The sum of the trapezoidal areas for }{ }^{27} \mathrm{Al}} \times \frac{{ }^{27} \mathrm{Al} \text { hourly infusion rate } \times \text { time }}{{ }^{26} \mathrm{Al} \text { dose }}
$$


Time to maximum serum ${ }^{26} \mathrm{Al}$ concentration $\left(\mathrm{T}_{\max }\right)$ and the maximum concentration $\left(\mathrm{C}_{\max }\right)$ were calculated using WinNonLin. Kruskal-Wallis tests and Dunn's multiple comparison tests (when the Kruskal-Wallis test was significant) were used to test for differences in the oral bioavailability, $\mathrm{T}_{\max }$, and $\mathrm{C}_{\max }$ of $\mathrm{Al}$ from the tea infusion compared to results previously obtained using the same procedure: $1 \%$ and $2 \%$ acidic SALP in a biscuit (Yokel and Florence, 2006), 1.5 and 3\% basic SALP in a cheese (Yokel et al., 2008), and from water (Yokel et al., 2001; Zhou et al., 2008). This test was used because the results had significantly different variances. $P<0.05$ was accepted as statistically significant.

\section{Results and Discussion}

Each rat received $1.37 \pm 0.2 \mathrm{nCi}{ }^{26} \mathrm{Al}$ in the tea infusion. Each rat's serum ${ }^{26} \mathrm{Al}$ results were normalized to its ${ }^{26} \mathrm{Al}$ dose. The BUN values ranged from 7.6 to $15.1 \mathrm{mg} / \mathrm{dl}$ and the serum creatinine values were $\leq 0.2 \mathrm{mg} / \mathrm{dl}$, well within normal limits ( $<30$ and $1 \mathrm{mg} / \mathrm{dl}$, respectively).

Pre-dosing serum ${ }^{26} \mathrm{Al}$ ranged from 0.1 to 2.4 (mean \pm S.D. $0.62 \pm 0.73$ ) pg/l. Only 1 of the 8 samples from the non- ${ }^{26} \mathrm{Al}$-dosed rat exceeded the criterion for acceptance of post-treatment serum ${ }^{26} \mathrm{Al}$ concentrations, indicating no appreciable cross-contamination. Peak serum $26 \mathrm{Al}$ concentrations after oral $26 \mathrm{Al}$ dosing in tea ranged from 326 to $962 \mathrm{pg} / \mathrm{l}$. The oral ${ }^{26} \mathrm{Al}$ dose increased peak serum ${ }^{26} \mathrm{Al} 525$ - to 1550 -fold above mean pre-treatment values. The time course of serum ${ }^{26} \mathrm{Al}$ following oral ${ }^{26} \mathrm{Al}$ dosing is shown in Figure 1. Peak serum ${ }^{26} \mathrm{Al}$ concentration occurred in the $1 \mathrm{~h}$ sample in 6 rats and the $2 \mathrm{~h}$ sample in 2 rats. As the mean terminal half-life of ${ }^{26} \mathrm{Al}$ elimination was $10.4 \pm 1.8 \mathrm{~h}$ blood was obtained for $>3$ half-lives; more than sufficient time to determine the area under the ${ }^{26} \mathrm{Al}$ (concentration $\times$ time) curve (AUC). The $\mathrm{AUC}_{\text {time to last sample }}$ was $\geq 97.9 \% \mathrm{AUC}_{\text {infinity }}$ in all cases, indicating that samples were collected for sufficient time to adequately determine oral $\mathrm{Al}$ absorption. Oral bioavailability results are shown in Table 1. Oral Al bioavailability from the tea infusion was greater than previously observed from water and two representative foods containing the food additive SALP in studies that used the same methods. This difference reached statistical significance only for $\mathrm{Al}$ incorporated into acidic SALP in a baked good. $\mathrm{T}_{\max }$ and $\mathrm{C}_{\max }$ of the tea infusion (Table 1) were not different from water, but were significantly less and greater, respectively, from the combined $1 \%$ and $2 \%$ acidic SALP in biscuit and 1.5 and 3\% basic SALP in cheese results. Al from the tea infusion was rapidly absorbed, comparable to that seen from water (Figure 1 compared to Figure 2). The $\mathrm{T}_{\max }$ of $\mathrm{Al}$ from tea infusion is consistent with the apparent site of $\mathrm{Al}$ absorption, the upper intestine (Froment et al., 1989).

The typical tea bag contains $2 \mathrm{~g}$ of finely ground tea. The dry tea leaf used to prepare tea beverage often contains 500 to $1000 \mathrm{mg} \mathrm{Al} / \mathrm{kg}$ (Scancar et al, 2003), Many studies have shown that 20 to $35 \%$ of the $\mathrm{Al}$ in tea leaves is solubilized into the first infusion when the beverage is prepared, with decreasing amounts in subsequent infusions, e.g. (Wang et al., 1994).

No prior studies adequately determined oral $\mathrm{Al}$ absorption from tea beverage. Fujii et al. (2002) gave Oolong tea infusion or Al citrate ( $16.7 \mathrm{ml} / \mathrm{kg}$ of $11.9 \mathrm{mg} \mathrm{Al} / 1 ; 0.2 \mathrm{mg} \mathrm{Al} / \mathrm{kg}$ ), or water, to rats. Blood samples were obtained 0.5, 1, 2 and $3 \mathrm{~h}$ later. The serum Al AUC was 4fold greater for Al citrate than for Oolong tea. These authors also gave rats $15 \mathrm{ml} / \mathrm{kg}$ of Oolong, green or black tea, containing $11.9 \mathrm{ppm}(\mathrm{mg} / \mathrm{l}) \mathrm{Al}(0.18 \mathrm{mg} \mathrm{Al} / \mathrm{kg}$ ), or water (Fujii et al., 2002). The AUCs for $\mathrm{Al}$ for green and black teas were 238 and $86 \%$ of those seen for Oolong tea, suggesting greater relative Al bioavailability from green than Oolong or black teas. However, oral Al bioavailability cannot be calculated from these results because they lack the AUC following iv administration (Bauer, 2006).

Increased urinary $\mathrm{Al}$ concentration was seen in 6 humans in the $12 \mathrm{~h}$ after consumption of 1.2 1 of tea compared to water (Koch et al., 1988). The authors did not report urine volume. If urine 
volume was comparable after tea and water consumption, as reported by Powell et al. (1993), urinary Al output was greater following tea, suggesting Al absorption from tea. In one subject total $24 \mathrm{~h}$ urinary Al output was $0.02 \mathrm{mg}$ after consumption of 21 of tea containing 5.9 mg Al compared to $0.004 \mathrm{mg} \mathrm{Al}$ in the urine after consumption of 21 of water (Powell et al., 1993). They did not calculate oral Al bioavailability from their results. Their results suggest $0.27 \%$ Al bioavailability from tea, based on calculations conducted by one of the authors of the present report. In another study, 4 humans who consumed 21 of tea containing $8 \mathrm{mg} \mathrm{Al}$ eliminated an average of $0.003 \mathrm{mg} \mathrm{Al}$ within the subsequent $7 \mathrm{~h}$ in their urine (Gardner and Gunn, 1995). The authors did not calculate oral Al bioavailability from their results. Their results suggest $0.04 \% \mathrm{Al}$ bioavailability from tea, based on calculations conducted by one of the authors of the present report. However, Gardner and Gunn (1995) only collected urine for $7 \mathrm{~h}$ after tea consumption. Seven $\mathrm{h}$ is not sufficient time to accurately determine total Al output from the $\mathrm{Al}$ consumed in the tea. In the human, only $62 \%$ of Al eventually excreted in the urine appeared within the first $24 \mathrm{~h}$ (Priest et al, 1996). Therefore, $0.04 \%$ would be an underestimate of oral Al bioavailability from tea. (Wu et al., 1997) reported the results of a study in four humans who consumed 0.91 of tea prepared from Oolong or Long-Jin (green) tea, containing 3.68 and $1.14 \mathrm{mg} \mathrm{Al}$. They reported $24 \mathrm{~h}$ urine $\mathrm{Al}$ output from which one of the authors of the present report calculated that 0.5 and $1.05 \%$ of the ingested $\mathrm{Al}$ was excreted in their urine in the subsequent $24 \mathrm{~h}$, above urine $\mathrm{Al}$ excretion after consuming water, assuming no changes in dietary Al intake.

This report describes the first adequately designed study to determine the oral bioavailability of Al from tea. This study utilized eight rats, whereas the three prior studies from which one can estimate oral Al bioavailability from tea employed 1, 4 and 4 humans. We followed $\mathrm{Al}$ for $60 \mathrm{~h}$ after its administration $v s .7$ to $24 \mathrm{~h}$ in the prior studies. ${ }^{26} \mathrm{Al}$ was utilized as a tracer, as described by Yokel et al. (2001), providing a less ambiguous estimate of oral Al absorption due to its lack of presence in the environment and rats in the absence of its administration. Studies with ${ }^{27} \mathrm{Al}$ have the problem of differentiating administered from background ${ }^{27} \mathrm{Al}$. The results calculated from one human (Powell et al., 1993) followed for $24 \mathrm{~h}$ and four humans followed for $24 \mathrm{~h}$ (Wu et al., 1997), in which urinary Al excretion was used to estimate $\mathrm{Al}$ absorption, given the limitations of that method, are reasonably consistent with the present results that suggest oral $\mathrm{Al}$ bioavailability from tea beverage is $0.37 \%$.

In recent years, a number of studies have been conducted to address the hypothesis that $\mathrm{Al}$ in drinking water contributes to AD (Krewski et al., 2007). Many showed a significantly higher incidence of $\mathrm{AD}$ among people living in districts that had more $\mathrm{Al}$ in the drinking water than in people drinking water that contained less Al (Krewski et al., 2007). To characterize the risk of Alinduced adverse health effects from Al exposure in drinking water, (Krewski et al., 2007) determined the margin of exposure (MOE; ratio of the exposure level of concern to the exposure level) for neurological endpoints (e.g. AD) in relation to oral Al exposure from drinking water. The results revealed a MOE $\geq 1$, suggesting the neurological (AD) health endpoint associated with oral $\mathrm{Al}$ exposure deserves scrutiny. Given the potential high $\mathrm{Al}$ concentration in tea beverage, considerable consumption of tea by some people, and oral bioavailability of $\mathrm{Al}$ from tea that is at least as great as from water, the relative source contribution from tea beverage should be considered with heightened concern. If drinking water presents health risks from $\mathrm{Al}$ exposure, one would anticipate tea to do so to a greater extent. In fact, three studies have shown a non-significantly greater odds ratio for AD in those who consume more tea (Broe et al., 1990; Anonymous, 1994; Forster et al., 1995), whereas one study found a non-significantly lower odds ratio (Rogers and Simon, 1999). Further testing of the hypothesis that $\mathrm{Al}$ contributes to $\mathrm{AD}$ may be more warranted with studies focusing on total daily food intake, including tea consumption and other foods containing appreciable amounts of $\mathrm{Al}$, than drinking water. 
In summary, oral Al bioavailability from tea was $0.37 \%$. Studies using the same methods showed 0.28 and $0.29 \%$ of $\mathrm{Al}$ was orally absorbed from water (Yokel et al., 2001; Zhou et al., 2008). Given that oral Al bioavailability from tea was not significantly different from water and tea contains much more $\mathrm{Al}$ than water, tea contributes more $\mathrm{Al}$ than does water to the body burden of tea drinkers. It has been cautioned that the potential for Al toxicity from drinking tea should not be overlooked, particularly among people who consume considerable tea that has a high $\mathrm{Al}$ content, as occurred among some people in China who consume poor quality tea made from older leaves and branches (Wong et al., 1998). The present results suggest that, among foods and beverages, tea can be a significant contributor to systemic Al.

\section{Abbreviations}

$\mathrm{AD}$, Alzheimer's disease; Al, aluminum; AUC, area under the (concentrationxtime) curve; $\mathrm{C}_{\max }$, maximum serum concentration; $\mathrm{F}$, oral bioavailability; SALP, sodium aluminum phosphate; $\mathrm{T}_{\max }$, time to maximum serum concentration.

\section{Acknowledgement}

This work was supported by NIH Grant R01 ES11305.

\section{References}

Anonymous. The Canadian study of health and aging: Risk factors for Alzheimer's disease in Canada. Neurology 1994;44:2073-2080. [PubMed: 7969962]

Bauer, LA. Clinical pharmacokinetics handbook. New York: McGraw-Hill, Medical Pub. Division; 2006. p. 16

Broe GA, Henderson AS, Greasey H, McCusker E, Korten AE, Jorm AF, Longley W, Anthony JC. A case-control study of Alzheimer's disease in Australia. Neurology 1990;40:1698-1707. [PubMed: 2146525]

Flarend, R.; Elmore, D. Aluminum-26 as a biological tracer using accelerator mass spectrometry. In: Zatta, P.; Alfrey, AC., editors. Aluminum toxicity in infant's health and disease. Singapore, London: World Scientific; 1998. p. 16-39.

Flaten TP. Aluminium in tea-concentrations, speciation and bioavailability. Coor. Chem. Rev 2002;228:385-395.

Forster DP, Newens AJ, Kay DW, Edwardson JA. Risk factors in clinically diagnosed presenile dementia of the Alzheimer type: a case-control study in northern England. J. Epidemiol. Comm. Health 1995;49:253-258.

Froment DP, Molitoris BA, Buddington B, Miller N, Alfrey AC. Site and mechanism of enhanced gastrointestinal absorption of aluminum by citrate. Kidney Int 1989;36:978-984. [PubMed: 2601265]

Fujii W, Kusumoto A, Nakada T, Suwa Y. Gastrointestinal absorption of aluminum from teas in rats. J. Food Sci 2002;67:2552-2554.

Gardner MJ, Gunn AM. Speciation and bioavailability of aluminium in drinking water. Chem. Speciation and Bioavail 1995;7:9-16.

Hayacibara MF, Queiroz CS, Tabchoury CPM, Cury JA. Fluoride and aluminum in teas and tea-based beverages. Revista de Saude Publica 2004;38:100-105. [PubMed: 14963548]

Koch KR, Pougnet MA, de Villiers S, Monteagudo F. Increased urinary excretion of Al after drinking tea. Nature 1988;333:122. [PubMed: 3367985]

Kochian, LV.; Jones, DL. Aluminum toxicity and resistance in plants. In: Yokel, RA.; Golub, MS., editors. Research Issues in Aluminum Toxicity. Washington, D.C: Taylor and Francis; 1997. p. 69-89.

Krewski D, Yokel RA, Nieboer E, Borchelt D, Cohen J, Harry J, Kacew S, Lindsay J, Mahfouz AM, Rondeau V. Human health risk assessment for aluminium, aluminium oxide, and aluminium hydroxide. J. Toxicol. Environ. Health, Part B: Crit. Rev 2007;10:1-269. 
Martyn CN, Barker DJ, Osmond C, Harris EC, Edwardson JA, Lacey RF. Geographical relation between Alzheimer's disease and aluminum in drinking water. Lancet 1989;i:59-62. [PubMed: 2562879]

Pennington JA, Schoen SA. Estimates of dietary exposure to aluminium. Food Addit. Contam 1995;12:119-128. [PubMed: 7758626]

Pharsight. WinNonLn, V. 5.2. Mountain View, CA: Pharsight Corporation; 2008.

Polak TB, Milacic R, Pihlar B, Mitrovic B. The uptake and speciation of various Al species in the Brassica rapa pekinensis. Phytochem 2001;57:189-198.

Powell JJ, Greenfield SM, Parkes HG, Nicholson JK, Thompson RP. Gastro-intestinal availability of aluminium from tea. Food Chem. Toxicol 1993;31:449-454. [PubMed: 8514217]

Reto M, Figueira ME, Filipe HM, Almeida CM. Chemical composition of green tea (Camellia sinensis) infusions commercialized in Portugal. Plant Foods Hum Nutr 2007;62:139-144. [PubMed: 17899383]

Rogers MAM, Simon DG. A preliminary study of dietary aluminium intake and risk of Alzheimer's disease. Age Ageing 1999;28:205-209. [PubMed: 10350420]

Rowland, M.; Tozer, TN. Concepts and Applications. Media, PA: Williams \& Wilkins; 1995. Clinical Pharmacokinetics.

Sepe A, Costantini S, Ciaralli L, Ciprotti M, Giordano R. Evaluation of aluminium concentrations in samples of chocolate and beverages by electrothermal atomic absorption spectrometry. Food Addit. Contam 2001;18:788-796. [PubMed: 11552746]

Sjögren, B.; Iregren, A.; Elinder, C-G.; Yokel, RA. Aluminum. In: Nordberg, GF.; Fowler, B.; Nordberg, M.; Friberg, LT., editors. Handbook on the toxicology of metals. Amsterdam: Elsevier; 2007. p. 339-352.

Stauber JL, Florence TM, Davies CM, Adams MS, Buchanan SJ. Bioavailability of Al in alum-treated drinking water. Journal AWWA (American Water Works Association) 1999;91:84-93.

Steinhausen C, Kislinger G, Winklhofer C, Beck E, Hohl C, Nolte E, Ittel TH, Alvarez-Bruckmann MJ. Investigation of the aluminium biokinetics in humans: a 26Al tracer study. Food Chem. Toxicol 2004;42:363-371. [PubMed: 14871578]

UKMAFF (United Kingdom Ministry of Agriculture Fisheries and Food). The thirty ninth report of the Steering Group on Chemical Aspects of Food Surveillance. Food Surveillance Paper No. 39. London: HMSO (Her Magesty's Stationery Office); 1993. Aluminium in food. $48+3$ appendices.

Wang L, Su DZ, Wang YF. Studies on the aluminium content in Chinese foods and the maximum permitted levels of aluminum in wheat flour products. Biomed. Environ. Sci.: BES 1994;7:91-99.

Wong MH, Zhang ZQ, Wong JWC, Lan CY. Trace metal contents ( $\mathrm{Al}, \mathrm{Cu}$ and $\mathrm{Zn}$ ) of tea: tea and soil from two tea plantations, and tea products from different provinces of China. Environ. Geochem. Health 1998;20:87-94.

Wu J, Zhou CY, Wong MK, Lee HK, Ong CN. Urine levels of aluminum after drinking tea. Biol. Trace Elem. Res 1997;57:271-280. [PubMed: 9359993]

Yokel, RA. Aluminum. In: Merian, E.; Anke, M.; Ihnat, M.; Stoeppler, M., editors. Elements and their compounds in the environment, Occurrence, analysis and biological relevance. Vol. Vol. 2. Weinheim, Germany: Wiley-VCH; 2004. p. 635-658.

Yokel RA, Florence RL. Aluminum bioavailability from the approved food additive leavening agent acidic sodium aluminum phosphate, incorporated into a baked good, is lower than from water. Toxicology 2006;227:86-93. [PubMed: 16949191]

Yokel RA, Hicks CL, Florence RL. Aluminum bioavailability from basic sodium aluminum phosphate, an approved food additive emulsifying agent, incorporated in cheese. Food Chem. Toxicol 2008;46:2261-2266. [PubMed: 18436363]

Yokel RA, McNamara PJ. Aluminum toxicokinetics: An updated mini-review. Pharmacology and Toxicology 2001;88:159-167. [PubMed: 11322172]

Yokel RA, Rhineheimer SS, Brauer RD, Sharma P, Elmore D, McNamara PJ. Aluminum bioavailability from drinking water is very low and is not appreciably influenced by stomach contents or water hardness. Toxicology 2001;161:93-101. [PubMed: 11295258]

Zhou Y, Harris WR, Yokel RA. The influence of citrate, maltolate and fluoride on the gastrointestinal absorption of aluminum at a drinking water-relevant concentration: $\mathrm{A}^{26} \mathrm{Al}$ and ${ }^{14} \mathrm{C}$ study J. Inorganic Biochem 2008;102:798-808. 


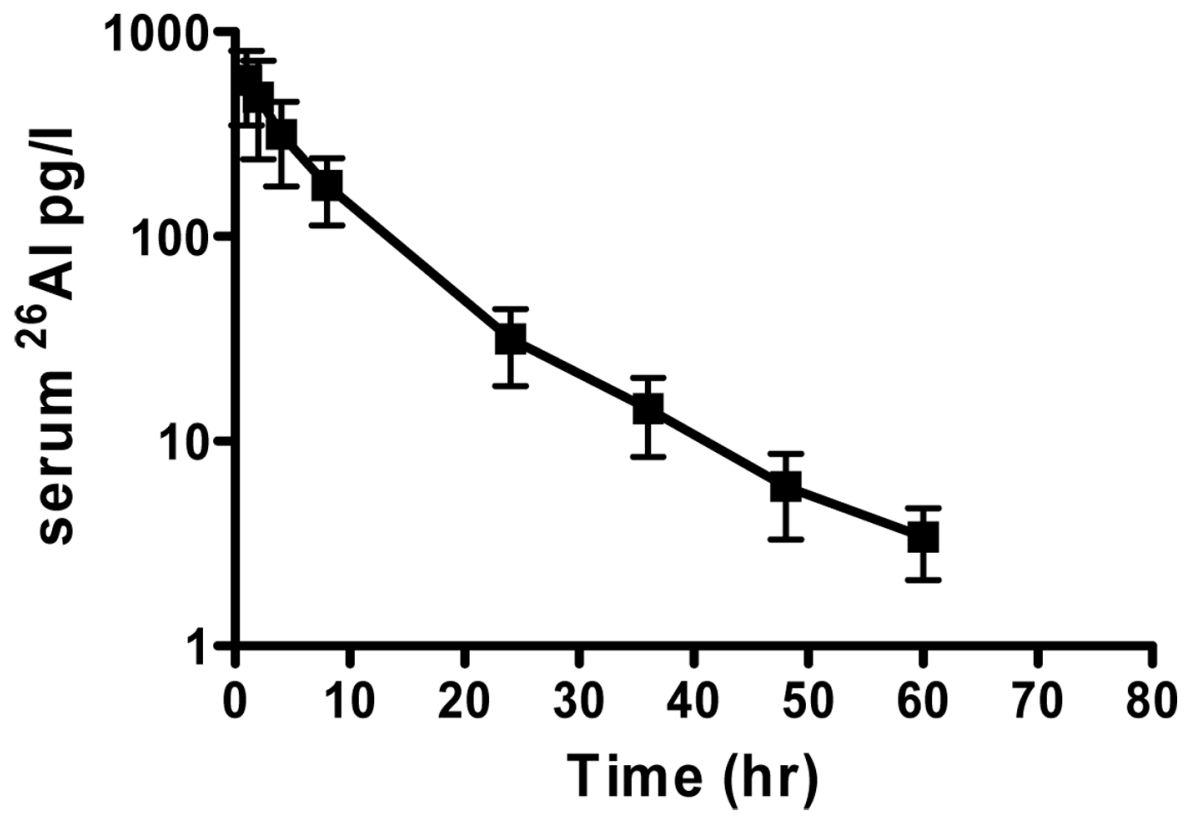

Figure 1.

Concentration of ${ }^{26} \mathrm{Al}$ in serum versus time after consumption of ${ }^{26} \mathrm{Al}$ in a tea infusion. The values are mean \pm SD from 8 rats. 


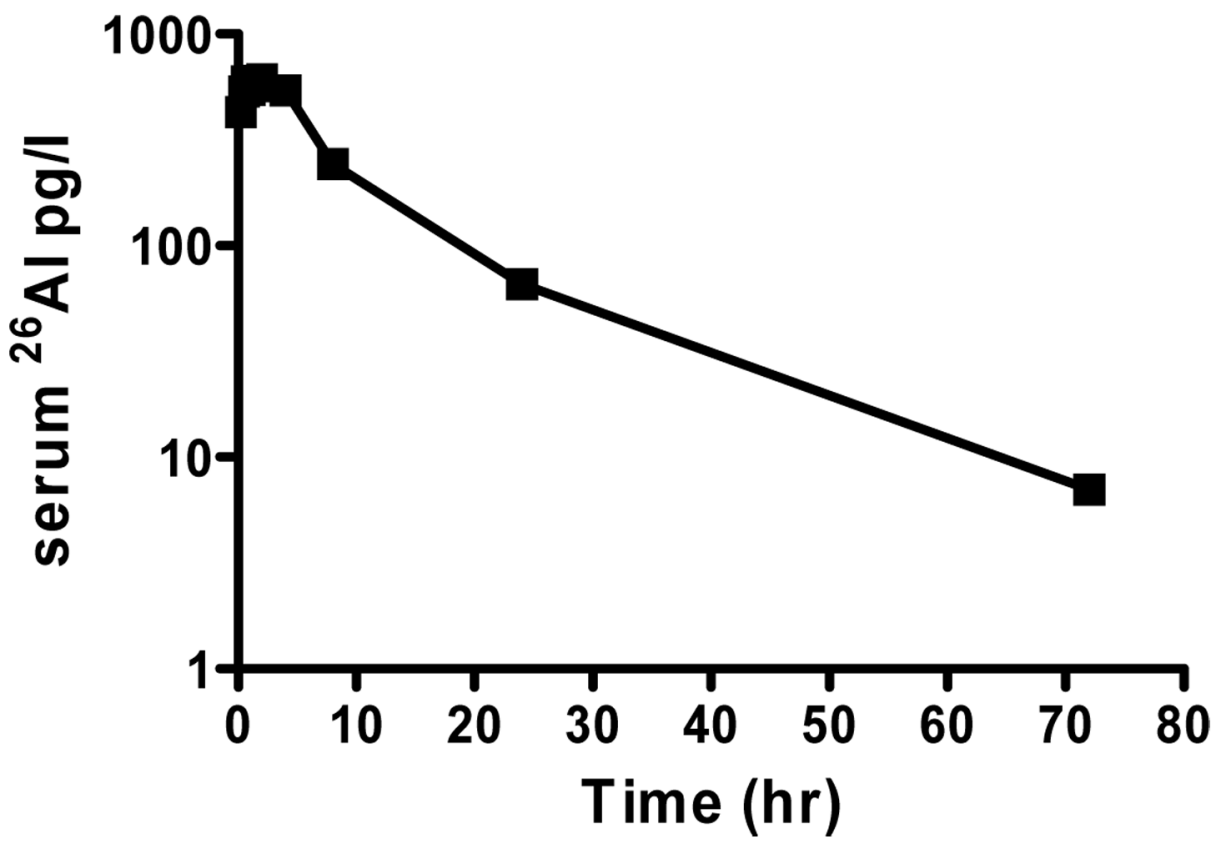

Figure 2.

Concentration of ${ }^{26} \mathrm{Al}$ in serum versus time after consumption of ${ }^{26} \mathrm{Al}$ in water. The values are mean from 5 rats at $0.25,0.5,0.75 \mathrm{~h} ; 24$ to 26 rats at $1 \mathrm{~h} ; 5$ rats at 1.25 and $1.5 \mathrm{~h} ; 24$ to 26 rats at 2, 4, 8 and $24 \mathrm{~h}$ and 3 rats at $72 \mathrm{~h}$. 
